\title{
Comparison of three inhaled non-steroidal anti-inflammatory drugs on the airway response to sodium metabisulphite and adenosine 5'-monophosphate challenge in asthma
}

\author{
Millie Wang, Antoni Wisniewski, Ian Pavord, Alan Knox, Anne Tattersfield
}

\begin{abstract}
Background - Non-steroidal

antiinflammatory drugs (NSAIDs) are used to assess the role of prostaglandins in asthma but their effects on bronchoconstrictor challenges have been inconsistent. The effects of three nebulised nonsteroidal anti-inflammatory drugs on the airway response to inhaled sodium metabisulphite (MBS) and adenosine 5'monophosphate (AMP) were compared in the same asthmatic subjects to see whether contractile prostaglandins were involved in MBS or AMP induced bronchoconstriction. A possible protective effect of the osmolarity or pH of the inhaled solutions was also assessed.

Methods - Two double blind placebo controlled studies were carried out. In study 1, 15 non-aspirin sensitive patients with mild asthma attended on four occasions and inhaled $5 \mathrm{ml}$ of lysine aspirin ( $\mathrm{L}-$ aspirin) $900 \mathrm{mg}$, indomethacin $50 \mathrm{mg}$, sodium salicylate $800 \mathrm{mg}$, or saline 20 minutes before an inhaled MBS challenge. On four further occasions 14 of the patients inhaled the same solutions followed by an inhaled AMP challenge. In study 2,10 of the patients attended on four additional occasions and inhaled $5 \mathrm{ml}$ of $0.9 \%, 3 \%, 10 \%$, or $9.5 \%$ saline with indomethacin $50 \mathrm{mg} 20$ minutes before an inhaled MBS challenge.
\end{abstract}

Results - In study 1 inhaled lysine aspirin had a similar effect on MBS and AMP induced bronchoconstriction, increasing the provocative dose causing a $20 \%$ fall in FEV $_{1}\left(\mathbf{P D}_{20}\right)$ by 1.29 (95\% CI 0.54 to 2.03$)$ and $1.23(95 \%$ CI 0.53 to 1.93$)$ doubling doses, respectively. Indomethacin increased the MBS $\mathbf{P D}_{20}$ and AMP $\mathbf{P D}_{20}$ by $0.64(95 \% \mathrm{CI}-0.1$ to 1.38$)$ and $0.99(95 \% \mathrm{CI}$ 0.29 to 1.69 ) doubling doses, respectively. Sodium salicylate had no significant effect on either challenge. The two solutions causing most inhibition were the most acidic and the most alkaline. In study 2 inhaled $9.5 \%$ saline with indomethacin (osmolarity $3005 \mathrm{mOsm} / \mathrm{kg}$ ) increased the MBS $\mathrm{PD}_{20}$ by 1.1 doubling doses (95\% CI 0.2 to 2.0$)$ compared with only $0.09(95 \%$ CI -0.83 to 1.0$)$ and $0.04(95 \%$ CI -0.88 to
0.95) doubling doses with $3 \%$ saline (918 $\mathrm{mOsm} / \mathrm{kg}$ ) and $10 \%$ saline $(2994 \mathrm{mOsm} /$ kg), respectively.

Conclusions - Inhaled L-aspirin and indomethacin have broadly similar protective effects against MBS and AMP induced bronchoconstriction in the doses given, although the effect of indomethacin on MBS was not quite statistically significant. The osmolarity and $\mathrm{pH}$ of the solutions did not appear to be important determinants of the response. The effect of $L$-aspirin and indomethacin is likely to be the result of cyclooxygenase inhibition reducing the production of contractile prostaglandins during MBS and AMP challenge.

(Thorax 1996;51:799-804)

Keywords: asthma, non-steroidal anti-inflammatory drugs, prostaglandins.

The cyclooxygenase products of arachidonic acid metabolism include several potentbronchoactive prostaglandins (PGs) and thromboxane. Inhaled $\mathrm{PGF}_{2 \alpha}$ and $\mathrm{PGD}_{2}$ cause bronchoconstriction in patients with asthma ${ }^{1}$ whereas $\mathrm{PGE}_{2}$ protects against challenges that act indirectly on the airways including sodium metabisulphite, ${ }^{2}$ exercise, ultrasonically nebulised distilled water, ${ }^{34}$ and both the early and late responses to allergen. ${ }^{5}$

The role of endogenous prostaglandins and thromboxane in asthma is less clear and has been probed with non-steroidal antiinflammatory drugs (NSAIDs) which inhibit their production by the cyclooxygenase pathway and with thromboxane receptor antagonists. ${ }^{6}$ Ingestion and inhalation of NSAIDs cause bronchoconstriction in a small proportion of patients with asthma and, very occasionally, bronchodilatation. In most patients, however, they cause little change in resting lung function, suggesting that endogenous prostaglandins may not be important. Other studies, however, suggest that both constrictor and protective prostaglandins are active in asthmatic airways. Inhaled lysine aspirin, indomethacin, and sodium salicylate inhibit the late response to allergen ${ }^{7-9}$ and lysine aspirin and 
indomethacin protect against ultrasonically nebulised distilled water induced bronchoconstriction, ${ }^{10}$ suggesting that bronchoconstrictor tone in these circumstances is prostaglandin dependent. Inhibitory prostaglandins such as $\mathrm{PGE}_{2}$ appear to have a role in the development of refractoriness following indirectly acting challenges since this is inhibited by NSAIDs, and there is some evidence to suggest that they mediate the effects of frusemide although this has been less consistent. The protective effect of frusemide on bronchoconstriction following exercise was attenuated by oral indomethacin in one study ${ }^{11}$ but augmented by inhaled lysine aspirin $^{12}$ and oral flurbiprofen ${ }^{13}$ in others. Thus, there is evidence that both constrictor and protective prostaglandins play a part in determining airway calibre under certain circumstances, although there are many unexplained inconsistencies in the literature.

One problem when comparing studies on the effects of NSAIDs in asthma is the considerable variation in the drugs given, doses, routes of administration, osmolarity and $\mathrm{pH}$ of the inhaled solutions, and the bronchial challenge tests used to assess the response. NSAIDs are a non-homogeneous group of chemical compounds with varying effects on the two cyclooxygenase isoenzymes currently identified, COX-1 and COX-2. ${ }^{14}$ Discrepancies in the literature may therefore be due to differences in the drugs, the methodologies used, or to differences in osmolarity or $\mathrm{pH}$ of the inhaled solutions.

The bronchoconstriction caused by sodium metabisulphite is thought to act via release of sulphur dioxide $\left(\mathrm{SO}_{2}\right)^{15}$ and activation of neural pathways. ${ }^{16} 17$ In contrast, the bronchoconstriction caused by inhalation of adenosine and its related nucleotide, adenosine 5'monophosphate (AMP), appears to be largely due to histamine release from primed airway mast cells; ${ }^{18}{ }^{19}$ selective $H_{1}$-receptor antagonists such as terfenadine inhibit the response to $\mathrm{AMP}^{20}$ in patients with asthma but not the response to sodium metabisulphite. ${ }^{21}$ The effect of inhaled NSAIDs on the airway response to inhaled MBS and AMP has not been studied. We have therefore compared the protective effect of three nebulised NSAIDs against inhaled MBS and AMP induced bronchoconstriction in asthmatic subjects who were not sensitive to aspirin to see whether contractile prostaglandins were involved in these challenges. We also assessed whether the osmolarity or $\mathrm{pH}$ of the inhaled solutions were related to any protective effect.

\section{Methods}

SUBJECTS

Fifteen non-smoking subjects (one woman) aged 21-51 years with mild asthma and no history of aspirin induced asthma were studied. Twelve were atopic (two or more positive skin prick tests to common allergens). All had asthma that was well controlled, a forced expiratory volume in one second $\left(\mathrm{FEV}_{1}\right)$ greater than $70 \%$ predicted, and no evidence of bronchoconstriction in response to inhaled lysine aspirin in the laboratory (see below). All were taking an inhaled $\beta_{2}$ agonist as required, six were taking inhaled beclomethasone (100$200 \mu \mathrm{g}$ per day), and one took oral loratadine as required for rhinitis. Inhaled $\beta$ agonists were withheld for at least 10 hours and oral loratadine for at least 48 hours before each challenge. Subjects were asked to use only paracetamol for pain relief if required during the study period. The study was approved by the City Hospital ethics committee and all subjects gave written informed consent.

\section{MATERIALS}

The drugs and chemicals used in the study included lysine aspirin (Laboratoires Synthelabo, Paris, France), indomethacin meglumine (Liometacen, Chiesi Farmaceutici, Parma, Italy), sodium salicylate (E Merck, UK), saline $=0.9 \%(\mathrm{wt} / \mathrm{vol})$ sodium chloride (Steripak Ltd, UK), 30\% sodium chloride (Martindale Pharmaceuticals Ltd, Essex, UK), sodium metabisulphite (MBS) (Thornton Boss Ltd, UK), and adenosine 5'-monophosphate (AMP) (Sigma, Poole, Dorset, UK).

Forced expiratory volume in one second $\left(\mathrm{FEV}_{1}\right)$ was measured with a dry wedge spirometer (Vitalograph, Buckingham, UK) and the higher of two successive readings within $100 \mathrm{ml}$ was recorded.

Sodium metabisulphite and adenosine 5'monophosphate were dissolved freshly in saline to produce a doubling concentration range of $0.6-160 \mathrm{mg} / \mathrm{ml}$ for sodium metabisulphite and $3.12-200 \mathrm{mg} / \mathrm{ml}$ for adenosine 5'monophosphate. Solutions were delivered by a nebuliser attached to a breath actuated dosimeter (Mefar, Brescia, Italy) at a nebulisation time of one second, pause time six seconds, pressure $22 \mathrm{lb} / \mathrm{m}(152 \mathrm{kPa})$, output $10.3 \mu \mathrm{l}$ and $12.8 \mu \mathrm{l}$ per puff for MBS and AMP, respectively. Normal saline was inhaled initially with the subjects inspiring slowly through the mouthpiece from functional residual capacity to total lung capacity over three seconds after the nebuliser was triggered and then breath holding for three seconds. FEV 1 was measured after two minutes. If the response to saline was less than a $10 \%$ fall from baseline $\mathrm{FEV}_{1}$, subjects inhaled doubling doses of MBS or AMP until a $20 \%$ or greater fall in $\mathrm{FEV}_{1}$ was recorded or the maximum dose of MBS (135 $\mu \mathrm{mol})$ or AMP $(118 \mu \mathrm{mol})$ had been given.

\section{PROTOCOL}

\section{Screening study}

An initial inhaled aspirin challenge was performed using a disposable nebuliser (DeVilbiss, Somerset) according to the method of Phillips et al. $^{22} 1800 \mathrm{mg}$ lysine aspirin (Laspirin) powder (equivalent to aspirin 1000 mg) was made up freshly each day in $5 \mathrm{ml}$ saline to produce a $360 \mathrm{mg} / \mathrm{ml} \mathrm{L-aspirin} \mathrm{solu-}$ tion. This solution was diluted further in saline to produce doubling concentrations from 5.6 to $360 \mathrm{mg} / \mathrm{ml}$. Three $\mathrm{ml}$ of each solution was placed in the nebuliser which was driven by compressed air at $8 \mathrm{l} / \mathrm{min}$ (nebuliser output $0.41 \mathrm{ml} / \mathrm{min}$ ). Subjects wore a nose clip and inhaled five breaths of normal saline, inspira- 
tion slowing from functional residual capacity to total lung capacity followed by a three second breath hold. $\mathrm{FEV}_{1}$ was measured five minutes later and followed by 10 breaths of L-aspirin at 15 minute intervals in doubling concentrations starting at $5.6 \mathrm{mg} / \mathrm{ml}$. $\mathrm{FEV}_{1}$ was measured five, 10 , and 15 minutes after each concentration. The test was discontinued if the $\mathrm{FEV}_{1}$ fell more than $10 \%$ after saline or L-aspirin compared with the value after saline.

Subjects only entered the two main studies if $\mathrm{FEV}_{1}$ fell by less than $10 \%$ with the highest dose of L-aspirin $(360 \mathrm{mg} / \mathrm{ml})$. Both studies were double blind and placebo controlled.

\section{Study 1: Effect of three NSAIDs on the airway response to $M B S$ and $A M P$}

Subjects attended for eight visits at the same time of day, each visit separated by at least 72 hours. After resting for 15 minutes they inhaled one of the following drugs dissolved in $5 \mathrm{ml}$ saline and made up freshly by a second investigator: $900 \mathrm{mg} \mathrm{L}$-aspirin (equivalent to $500 \mathrm{mg}$ aspirin), $77.2 \mathrm{mg}$ indomethacin meglumine (equivalent to $50 \mathrm{mg}$ indomethacin), $800 \mathrm{mg}$ sodium salicylate, or placebo (saline). The solutions were administered using a jet nebuliser (Unineb, Unimed (UK) Ltd, Dorset, UK) and mask driven by compressed air at 8 $1 /$ min and run by regular breathing until the nebuliser mist was no longer visible (output $0.36 \mathrm{ml} / \mathrm{min}$ ). The same nebuliser was used throughout the study. The $\mathrm{pH}$ and osmolarity of the solutions were measured before administration by a $\mathrm{pH}$ meter (M82 Radiometer $\mathrm{A} / \mathrm{S}$, Copenhagen, Denmark) and an osmometer (Osmomat 030, Gonotec GmbH, Berlin, Germany). $\mathrm{FEV}_{1}$ was recorded before and at two, five, 10 and 20 minutes after treatment. At 20 minutes patients underwent an inhaled MBS challenge during the first four visits and an inhaled AMP challenge on the second four visits.

\section{Study 2: Osmolarity study}

Ten patients from the first study attended on four further occasions. $30 \%$ sodium chloride was diluted in sterile water to produce concentrations of $3 \%, 10 \%$, and $9.5 \%$ sodium chloride. Subjects inhaled $5 \mathrm{ml}$ of each of the following: $0.9 \%$ saline $(292 \mathrm{mOsm} / \mathrm{kg}), 3 \%$ saline $(918 \mathrm{mOsm} / \mathrm{kg}), 10 \%$ saline $(2994$ $\mathrm{mOsm} / \mathrm{kg}$ ), or $9.5 \%$ saline with indomethacin $50 \mathrm{mg}$ ( $3005 \mathrm{mOsm} / \mathrm{kg}) 20$ minutes before an inhaled MBS challenge as described above.

Based on our previous data, the study had $95 \%$ power to detect a difference of 1.4 doubling doses at the $5 \%$ level of significance.

\section{DATA ANALYSIS}

Two way analysis of variance (ANOVA) was used to compare baseline values of $\mathrm{FEV}_{1}$ and the change in $\mathrm{FEV}_{1}$ at two, five, 10, and 20 minutes after each drug. The dose of bronconstrictor agent causing a $20 \%$ fall in $\mathrm{FEV}_{1}$ from baseline $\left(\mathrm{PD}_{20} \mathrm{FEV}_{1}\right)$ was calculated by linear interpolation of the log dose/response curve. If the fall in $\mathrm{FEV}_{1}$ was less than $20 \%$ after the
Table $1 p H$ and osmolarity of the solutions placed in the nebuliser in studies 1 and 2

\begin{tabular}{lcc}
\hline & $p H$ & $\begin{array}{c}\text { Osmolarity } \\
(\mathrm{mOsm} / \mathrm{kg})\end{array}$ \\
\hline Study 1 & & \\
$\quad 0.9 \%$ saline & 5.80 & 295 \\
Lysine aspirin & 5.18 & 1734 \\
Sodium salicylate & 6.39 & 2100 \\
$\quad$ Indomethacin & 7.92 & 463 \\
Study 2 & & \\
0.9\% saline & 5.80 & 292 \\
3\% saline & 6.50 & 918 \\
10\% saline & 6.80 & 2994 \\
9.5\% saline + & 8.20 & 3005 \\
indomethacin & & \\
\hline
\end{tabular}

maximum dose of $135 \mu \mathrm{mol} \mathrm{MBS}$ or $118 \mu \mathrm{mol}$ AMP the curve was extrapolated by one doubling dose to provide an estimated $\mathrm{PD}_{20}$. If the estimate was greater than the next doubling dose this value $(270$ or $235 \mu \mathrm{mol})$ was used as a censored value. This occurred on 11 of 60 occasions after MBS challenge and on 14 of 56 occasions after AMP challenge. The distribution of censored values after saline, L-aspirin, sodium salicylate, and indomethacin were two, three, two, and four occasions, respectively, for MBS and one, five, four, and four occasions after AMP (for MBS one subject had censored values after all four solutions and one after all but sodium salicylate; for AMP one subject had censored values after all four solutions and two after all three NSAIDs). A censored value was used on five of 40 occasions of the $P_{20}$ MBS in study 2 (one, three, and one occasion after $0.9 \%$ saline, indomethacin with $9.5 \%$ saline, and 3\% saline, respectively; one subject had a censored value after all three solutions).

$\mathrm{PD}_{20}$ values were log transformed and are presented as geometric mean values. The log values were compared using ANOVA. The mean difference in $\mathrm{PD}_{20}$ values relative to saline are expressed as doubling doses with $95 \%$ confidence intervals (CI). The difference in doubling doses was calculated as: $[\log$ MBS or AMP $\mathrm{PD}_{20}$ (drug)] - [log MBS or AMP $\mathrm{PD}_{20}$ (saline)]/log 2 .

Results were calculated for all values including censored values. For study 1 we repeated the analysis excluding the two subjects who had a censored value on at least three of the four occasions. The results given refer to the analysis including all censored values unless otherwise stated.

\section{Results}

Study 1: Effect of three NSAIDs on $\mathrm{PD}_{20} \mathrm{MBS}$ and $P D_{20} A M P$

The drugs were well tolerated apart from sodium salicylate which caused short lived cough in all subjects and prevented two subjects from providing an $\mathrm{FEV}_{1}$ measurement two minutes after treatment. Only 14 of the 15 subjects were available for the AMP study. The $\mathrm{pH}$ of the solutions in the nebuliser ranged from 5.18 (L-aspirin) to 7.92 (indomethacin) and the osmolarity from 295 (saline) to 2100 $\mathrm{mOsm} / \mathrm{kg}$ (sodium salicylate) (table 1 ).

Mean baseline $\mathrm{FEV}_{1}$ did not differ significantly between the four MBS or four AMP 


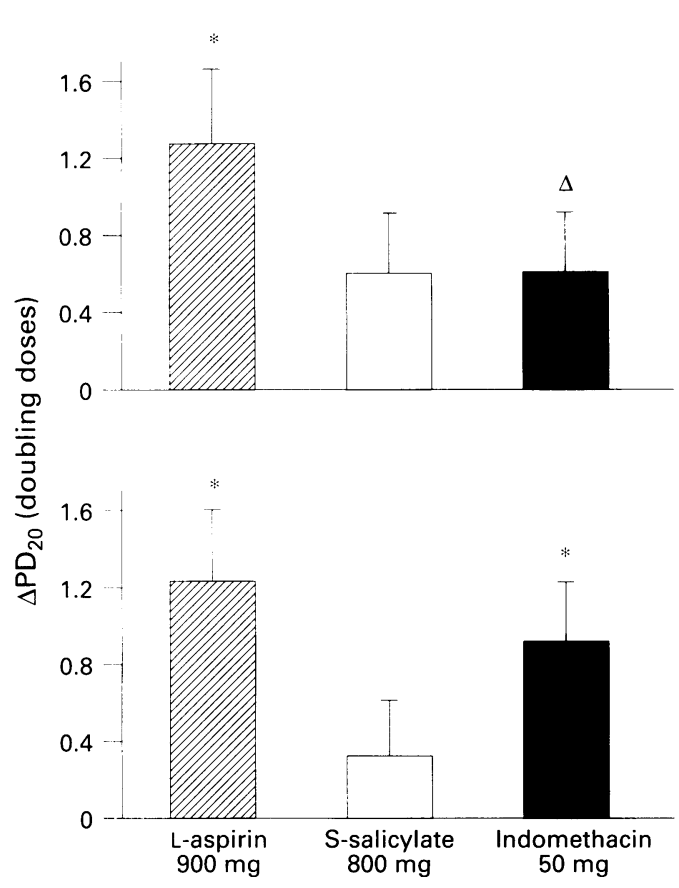

Figure 1 Mean (SE) difference in $P D_{20} M B S$ (above) and $P D_{20} A M P$ (below) after inhalation of lysine $(L)$ aspirin $900 \mathrm{mg}$, sodium $(S)$ salicylate $800 \mathrm{mg}$, and indomethacin $50 \mathrm{mg}$ relative to $0.9 \%$ saline. $* p<0.05$. $\Delta$ represents the difference for all subjects included.

study days. There was a small fall in $\mathrm{FEV}_{1}$ from baseline following inhalation of all the NSAIDs and saline ranging from $1.2 \%$ to $5.5 \%$. This was maximum at two minutes and had returned to $0-2 \%$ of baseline by 20 minutes. There were no significant differences between the four treatments at any time after inhalation.

$\mathrm{PD}_{20}$ MBS was higher after all three NSAID treatments relative to saline (fig 1) although the increase was only statistically significant for $\mathrm{L}$-aspirin. When compared with the $\mathrm{PD}_{20}$ values following saline, $\mathrm{PD}_{20} \mathrm{MBS}$ increased by 1.29 doubling doses with L-aspirin (95\% CI 0.54 to 2.03), by 0.64 doubling doses with indomethacin ( $95 \% \mathrm{CI}-0.1$ to 1.38 ), and by 0.63 doubling doses with sodium salicylate (95\% CI -0.11 to 1.38 ). There was no significant difference in $\mathrm{PD}_{20} \mathrm{MBS}$ values between the three drugs.

$\mathrm{PD}_{20}$ AMP was significantly higher after $\mathrm{L}$-aspirin and indomethacin (fig 1). When

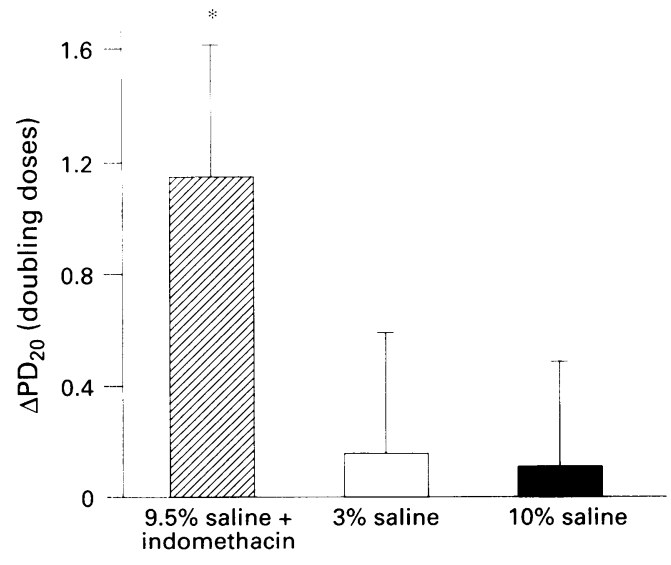

Figure 2 Mean (SE) difference in $P D_{20} M B S$ after inhalation of $3 \%$ saline, $10 \%$ saline, and $9.5 \%$ saline with indomethacin relative to $0.9 \%$ saline. $* p<0.05$ compared with $0.9 \%$ saline. compared with $\mathrm{PD}_{20}$ values following saline, $\mathrm{PD}_{20}$ AMP increased by 1.23 doubling doses with L-aspirin ( $95 \%$ CI 0.53 to 1.93 ), by 0.99 doubling doses with indomethacin (95\% CI 0.29 to 1.69 ), and by 0.31 doubling doses with sodium salicylate ( $95 \% \mathrm{CI}-0.39$ to 1.01 ). The difference in $\mathrm{PD}_{20}$ AMP between the three drugs was significant $(\mathrm{p}<0.05)$.

When the two subjects with three and four censored values were excluded the $\mathrm{PD}_{20} \mathrm{MBS}$ values increased to $1.49,0.84$, and 0.79 doubling doses after L-aspirin, indomethacin, and sodium salicylate, respectively, the increase for indomethacin being then statistically significant $(\mathrm{p}=0.05)$ and that for sodium salicylate being almost significant $(\mathrm{p}<0.1)$. The changes to the $\mathrm{PD}_{20}$ AMP values after the subjects with censored values were excluded were minor and did not alter the statistical significance of the findings.

\section{Study 2: Osmolarity study}

All four solutions were well tolerated. The $\mathrm{pH}$ ranged from $5.8(0.9 \%$ saline) to 8.2 (indomethacin with $9.5 \%$ saline) and the osmolarity from 292 ( $0.9 \%$ saline) to $3005 \mathrm{mOsm} / \mathrm{kg}$ (9.5\% saline with indomethacin) (table 1$)$. The mean baseline $\mathrm{FEV}_{1}$ did not differ significantly between the four study days.

There was a small increase from baseline in $\mathrm{FEV}_{1}$ following inhalation of normal saline $(0.4 \%)$ and a small decrease following the other three solutions (range 1.8-5.7\%) causing a difference between the four solutions which was statistically significant at two minutes after inhalation $(p=0.05)$ but not at five, 10 , or 20 minutes.

There was a significant difference in MBS $\mathrm{PD}_{20}$ between the three hyperosmolar solutions ( $p<0.05)$. When compared with the $\mathrm{PD}_{20}$ values following $0.9 \%$ saline, $\mathrm{MBS} \mathrm{PD}_{20}$ increased significantly by 1.1 doubling dose with indomethacin dissolved in $9.5 \%$ saline (95\% CI 0.2 to 2.0 ). The $3 \%$ and $10 \%$ saline solutions had little effect, altering $\mathrm{MBS} \mathrm{PD}_{20}$ by 0.09 (95\% CI -0.83 to 0.1$)$ and $0.04(95 \%$ CI -0.88 to 0.95 ) doubling doses, respectively (fig 2).

No significant difference in mean $\mathrm{PD}_{20}$ MBS values after saline was seen in the 10 patients who took part in studies 1 and 2 (geometric mean $4.9 \mu \mathrm{mol}$ and $7.5 \mu \mathrm{mol}$, respectively) or in the mean difference in $\mathrm{PD}_{20}$ values relative to saline after indomethacin alone in study 1 (0.93 doubling doses) and indomethacin with $9.5 \%$ saline in study 2 (1.1 doubling doses).

\section{Discussion}

We have compared the effects of L-aspirin, indomethacin, and sodium salicylate against two bronchoconstrictor challenges with different modes of action in patients with mild asthma who were not aspirin sensitive. Most patients with asthma show bronchial hyperresponsiveness to a large number of stimuli. These may act directly on airways smooth muscle or indirectly by stimulating neural 
reflexes (for example, metabisulphite) or by causing inflammatory cell mediator release (for example, exercise, AMP).

Three NSAIDs (L-aspirin, indomethacin, and sodium salicylate) were given by the same route to the same patients. None caused a change in $\mathrm{FEV}_{1}$ compared with saline in study 1 , confirming the absence of aspirin sensitive asthma in these patients. Pretreatment with inhaled L-aspirin (900 $\mathrm{mg}$ ) protected against bronchoconstriction induced by MBS and AMP when compared with saline, causing a 1.3 and 1.2 doubling dose increase in $\mathrm{PD}_{20}$ values, respectively. Inhaled indomethacin (50 $\mathrm{mg}$ ) shifted the dose-response curves of MBS and AMP challenge to the right by 0.6 and 1.0 doubling doses, respectively, although only the change with the 1.0 doubling dose was statistically significant. The small changes in $\mathrm{PD}_{20}$ MBS and AMP after inhaled sodium salicylate were not significant $(0.6$ and 0.3 doubling doses, respectively). The protective effect of inhaled indomethacin against MBS challenge may have been underestimated as four of the $\mathrm{PD}_{20}$ values after indomethacin were censored. When results from the two subjects with three or more censored values were excluded from the analysis the increase in $\mathrm{PD}_{20} \mathrm{MBS}(0.84$ doubling doses) was statistically significant.

Sodium salicylate is a weak cyclooxygenase inhibitor compared with both aspirin and indomethacin, ${ }^{23-25}$ and inhaled L-aspirin and indomethacin were active in our study whereas sodium salicylate was not. We have considered that the protection is due to cyclooxygenase inhibition.

In this study L-aspirin $900 \mathrm{mg}$ and indomethacin $50 \mathrm{mg}$ had broadly similar effects on the response to MBS and AMP - two bronchoconstrictor agents with different mechanisms of action. The same doses of L-aspirin and indomethacin caused a similar increase in ultrasonically nebulised water $\operatorname{PD}_{20}$ (2.1 and 1.6 doubling doses) compared with placebo in patients with asthma studied by Bianco. ${ }^{10}$ If the two drugs are causing protection through COX inhibition, both MBS and AMP induced bronchoconstriction must be dependent on release of contractile prostaglandins (or potentiated by prostaglandins in the airways) to a roughly similar extent. Sodium metabisulphite is thought to activate sensory nerves. ${ }^{21}{ }^{26} \mathrm{PGD}_{2}$ can enhance cholinergic neurotransmission. ${ }^{27}$ It has been shown that inhaled ipratropium bromide has a protective effect on the airway response to inhaled $\mathrm{PGD}_{2}{ }^{28}$ which suggests that $\mathrm{PGD}_{2}$ augments the parasympathetic contractile response prejunctionally and this is likely to involve the accelerated release of acetylcholine at the neuromuscular junction. ${ }^{27}$ It follows that $\mathrm{PGD}_{2}$ could potentiate the neural response to sodium metabisulphite. Inhibition of $\mathrm{COX}$ would reduce $\mathrm{PGD}_{2}$ production and thereby reduce the response to MBS. It has been shown that exogenous histamine induces release of $\mathrm{PGF}_{2 \alpha}$ in the airways in vitro. ${ }^{29}{ }^{30} \mathrm{It}$ is feasible that AMP induced histamine released from mast cells may produce some of its bronchoconstrictor effect by releasing contractile cyclooxygenase products. Thus,
COX inhibitors could attenuate AMP induced bronchoconstriction by this mechanism.

If the effect of aspirin and indomethacin is due to COX inhibition, their relative effects on MBS and AMP challenges should reflect their relative potencies as COX inhibitors. Cyclooxygenase exists as two isozymes, COX-1 and COX-2, COX-1 being a constitutive enzyme involved in cellular "housekeeping" functions ${ }^{31}$ whereas COX-2 is an inducible enzyme which is increased in the presence of inflammation ${ }^{32} 33$ and is responsible for the production of proinflammatory prostaglandins. When the relative potency of aspirin and indomethacin in inhibiting cyclooxygenase has been studied in broken cell, purified enzymes and intact cell preparations both drugs have been more potent inhibitors of COX-1 than COX-2, although the ratio of COX-1 to COX-2 inhibition has differed depending on the preparation studied..$^{34}$ It is difficult therefore to predict the relative potency of aspirin and indomethacin in inhibiting the two COX enzymes in the airways other than to say that both drugs are likely to be more selective for COX-1.

If the protective effect of NSAIDs in asthma is due to COX-2 inhibition, larger doses would be needed and this is more likely to be achieved by inhalation. High doses of inhaled NSAIDs have caused consistent inhibition of bronchoconstrictor responses as did oral indomethacin and flurbiprofen when given before adenosine induced bronchoconstriction. ${ }^{35}{ }^{36}$ Oral indomethacin ( $50 \mathrm{mg}$ three times daily) for three days did not protect against MBS induced bronchoconstriction, ${ }^{37}$ however, in contrast to the findings with inhaled indomethacin. The lower concentration of indomethacin in the airways following oral administration may not have been in the millimolar range needed to inhibit COX-2. ${ }^{14}$ Induction of COX-2 has not yet been demonstrated in mast cells from asthmatic patients, however.

We also considered whether production of 15-HETE (15-hydroxy eicosatetraenoic acid) might contribute to the protective effect of aspirin since it increases in response to aspirin in cultured ovine tracheal epithelial cells ${ }^{14}$ and can inhibit the 5-lipoxygenase pathway in neutrophils and T lymphocytes. ${ }^{38}{ }^{39}$ Since it is not increased with indomethacin ${ }^{14}$ it is unlikely to play an important part in the protection seen in our study.

In study 2 all three hyperosmolar solutions caused a small transient decrease in $\mathrm{FEV}_{1}$ from baseline compared with $0.9 \%$ saline which returned to placebo values after two minutes. Inhaled indomethacin (50 mg) with $9.5 \%$ saline protected against MBS challenge and the magnitude of this effect (1.1 doubling doses) was similar to that seen in study 1 with the same dose of indomethacin in $0.9 \%$ saline in the same subjects ( 0.9 doubling doses). The $3 \%$ and $10 \%$ saline solutions had no effect. The osmolarity of the solutions does not therefore appear to be an important determinant of the protective effect of indomethacin. Hyperosmolar saline induced bronchoconstriction has been shown to cause refractoriness ${ }^{40}$ but whether cross refractoriness occurs to affect 
other bronchial provocation challenges has not been studied. The lack of effect of hyperosmolar saline on subsequent challenge by MBS in our study may be because the hyperosmolar solution caused minor bronchoconstriction only.

The two solutions causing most inhibition were the most acidic (L-aspirin) and the most alkaline (indomethacin), which suggests that $\mathrm{pH}$ was not a major determinant of the protection seen.

Thus, inhaled L-aspirin and indomethacin have broadly similar effects against MBS and AMP induced bronchoconstriction in the doses given, although the effect of indomethacin on MBS was not quite statistically significant. The osmolarity and $\mathrm{pH}$ of the solutions did not appear to be important determinants of the response. The effect of L-aspirin and indomethacin is likely to be due to cyclooxygenase inhibition which reduces the production of contractile prostaglandins during MBS and AMP challenge.

The authors thank S Pacey for coding and randomising the drugs and J Williams for help with subject recruitment.

1 Hardy CC, Robinson C, Tattersfield AE, Holgate ST. The bronchoconstrictor effect of inhaled prostaglandin $\mathrm{D}$ in normal and asthmatic men. $N$ Engl f Med 1984;311:20913.

2 Pavord ID, Wisniewski A, Mathur R, Wahedna I, Knox AJ, Tattersfield AE. Effect of inhaled prostaglandin $E_{2}$ on bronchial reactivity to sodium metabisulphite and meth choline in patients with asthma. Thorax 1991;46:633-7.

3 Pasargiklian M, Bianco S, Allegra L, Moavero NE, Petrigni $\mathrm{G}$, Robuschi $\mathrm{M}$, et al. Aspects of bronchial reactivity to prostaglandins and aspirin in asthmatic patients. Respiration 1977;34:78-91.

4 Pasargiklian M, Bianco S, Allegra L. Clinical, functional and pathogenetic aspects of bronchial reactivity to prostaglandins $\mathrm{F}_{2 \alpha}, \mathrm{E}_{1}$, and $\mathrm{E}_{2}$. Adv Prostaglandin Thromboxane Res 1976;1:461-75.

5 Pavord ID, Wong CS, Williams J, Tattersfield AE. Effect of inhaled prostaglandin $\mathrm{E}_{2}$ on allergen-induced asthma. $\mathrm{Am}$ inhaled prostaglandin $\mathrm{E}_{2}$ on all

6 Fujimura M, Sakamoto S, Saito M, Miyake Y, Matsuda T. Effect of a thromboxane A2 receptor antagonist (AA2414) on bronchial hyperresponsiveness to methacholine in subjects with asthma. $\mathcal{f}$ Allergy Clin Immunol 1991; 87:23-7.

7 Bianco S, Refini RM, Pieroni MG. Protective effect of inhaled lysine acetylsalicylic acid on bronchial specific allergen challenge. Eur Respir f 1991;4:478s.

8 Sestini P, Pieroni MG, Refini RM. Protective effect of inhaled sodium salicylate on the early and late asthmatic reaction to allergen challenge. Eur Respir $71992 ; 5: 80 \mathrm{~s}$.

9 Pieroni M, Vaghi A, Refini RM. Inhaled indomethacin partially prevents the late but not the early bronchial allergic reaction. Am Rev Respir Dis 1993;147:25A.

10 Bianco S, Vaghi A, Pieroni MG, Robuschi M, Refini RM, Sestini P. Protective activity of inhaled nonsteroidal antiinflammatory drugs on bronchial responsiveness to ultrasonically nebulized water. $\mathcal{F}$ Allergy Clin Immunol 1992; 90:833-9. [Erratum $\mathcal{f}$ Allergy Clin Immunol 1993;91:966].

11 Pavord ID, Wisniewski AF, Tattersfield AE. Inhaled frusemide and exercise-induced asthma. Evidence of a role 143:A210.

12 Robuschi M, Scuri M, Vaghi A. Inhaled acetylsalicylic acid enhances the protective activity of furosemide against exercise-induced bronchoconstriction. Am Rev Respir Dis 1992;145:A729.

13 O'Connor BJ, Barnes PJ, Chung KF. Inhibition of sodium metabisulphite induced bronchoconstriction by frusemide in asthma: role of cyclooxygenase products. Thorax 1994; 49:307-11.

14 Meade EA, Smith WL, DeWitt DL. Differential inhibition of prostaglandin endoperoxide synthase (cyclooxygenase) isozymes by aspirin and other non-steroidal antiinflammatory drugs. $\mathcal{F}$ Biol Chem 1993;268:6610-4.
15 Fine JM, Gordon T, Sheppard D. The role of $\mathrm{pH}$ and ionic species in sulfur dioxide and sulfite-induced bronchoconstriction. Am Rev Respir Dis 1987;136:1122-6.

16 Nadel JA, Salem H, Tokiwa Y. Mechanism of bronchoconstriction during inhalation of sulfur dioxide. $\mathcal{F}$ Appl Physio 1965;20:164-7.

17 Nichol GM, Nix A, Chung KF, Barnes PJ. Characterisation of bronchoconstrictor responses to sodium metabisulphite aerosol in atopic subjects with and without asthma. Thorax 1989;44:1009-14.

18 Mann JS, Holgate ST, Renwick AG, Cushley MJ. Airway effects of purine nucleosides and nucleotides and release with bronchial provocation in asthma. $\mathcal{F}$ Appl Physiol 1986; 61:1667-76.

19 Cushley MJ, Tattersfield AE, Holgate ST. Inhaled adenosine and guanosine on airway resistance in normal and asthmatic subjects. $B r F$ Cli Pharmacol 1983;15:161-5.

20 Phillips GD, Rafferty P, Beasley R, Holgate ST. Effect of oral terfenadine on the bronchoconstrictor response to nhaled histamine and adenosine 5'-monophosphate in non-atopic asthma. Thorax 1987;42:939-45.

21 Dixon CSM, Ind PW. Metabisulfite induced bronchoconstriction: mechanisms. Am Rev Respir Dis 1988;137:238.

22 Phillips GD, Foord R, Holgate ST. Inhaled lysine-aspirin as a bronchoprovocation procedure in aspirin-sensitive a bronchoprovocation procedure in aspirin-sensitive and the role of histamine. $f$ Allergy Clin Immunol 1989;84:232-41.

23 Vane JR. Inhibition of prostaglandin synthesis as a mechanism of action for aspirin-like drugs. Nature 1971;231:232-5.

24 Cockbill SR, Heptinstall S, Taylor PM. A comparison of the abilities of acetylsalicylic acid, flurbiprofen and indomethacin to inhibit the release reaction and prostaglandin synthesis in human blood platelets. Br $\mathcal{F}$ Pharmacol 1979; 67:73-8.

25 Smith JB, Willis AL. Aspirin selectively inhibits prostaglandin production in human platelets. Nature 1971; 231:235-7.

26 Wright W, Zhang YG, Salome CM, Woolcock AJ. Effect of inhaled preservatives on asthmatic subjects. I. Sodium metabisulfite. Am Rev Respir Dis 1990;141:1400-4

27 Tamaoki J, Sekizawa K, Graf PD, Nadel JA. Cholinergic neuromodulation by prostaglandin $\mathrm{D}_{2}$ in canine airway smooth muscle. F Appl Physiol 1987;63:1396-400.

28 Beasley R, Varley J, Robinson C, Holgate ST. Cholinergicmediated bronchoconstriction induced by prostaglandin $\mathrm{D}_{2}$, its initial metabolite $9 \alpha, 11 \beta-\mathrm{PGF}_{2}$ and $\mathrm{PGF}_{2 \alpha}$ in asthma. Am Rev Respir Dis 1987;136:1140-4.

29 Platshon LF, Kaliner M. The effect of the immunologic release of histamine on human lung cyclic nucleotide levels and prostaglandin generation. $\mathcal{F}$ Clin Invest 1978; 632:1113-21

30 Adkinson NF, Newball HH, Findlay S, Adams K, Lichtenstein LM. Anaphylactic release of prostaglandins from human lung in vitro. Am Rev Respir Dis 1980;121:911-20.

31 Smith WL. The eicosanoids and their biochemical mechanisms of action. Biochem f 1989;259:315-24.

32 Kujubu DA, Herschman HR. Dexamethasone inhibits mitogen induction of the TIS 10 prostaglandin synthase/ cyclooxygenase gene. F Biol Chem 1992;267:7991-4.

33 Masferrer JL, Seibert K, Zweifel B, Needleman P. Endogenous glucocorticoids regulate an inducible cyclooxygenase enzyme. Proc Natl Acad Sci USA 1992 89:3917-2

34 Mitchell JA, Akarasereenont P, Thiemermann C, Flower RJ, Vane JR. Selectivity of nonsteroidal antiinflammatory drugs as inhibitors of constitutive and inducible cyclooxygenase. Proc Natl Acad Sci USA 1994;90:11693-7.

35 Crimi N, Palermo F, Polosa R, Oliveri R, Maccarrone C, Palermo B, et al. Effect of indomethacin on adenosineinduced bronchoconstriction. 7 Allergy Clin Immunol 1989;83:921-5.

36 Phillips GD, Holgate ST. The effect of oral terfenadine alone and in combination with flurbiprofen on the bronchoconstrictor response to inhaled adenosine 5, monophosphate in nonatopic asthma. Am Rev Respir Dis 1989;139:463-9.

37 Pavord ID, Wisniewski A, Tattersfield AE. Refractoriness to inhaled sodium metabisulphite in subjects with mild asthma. Eur Respir f 1994;7:50-4

38 Vanderhoek JY, Bryant RW, Bailey JM. Inhibition of leukotriene biosynthesis by the leukocyte product 15-hydroxy5,8,11,13-eicosatetraenoic acid. F Biol Chem 1980; 255:10064-6.

39 Goetzl EJ. Selective feed-back inhibition of the 5-lipoxygenation of arachidonic acid in human 5-lipoxygenation of arachidonic acid in human 101:344-50.

40 Belcher NG, Rees PJ, Clark TJ, Lee TH. A comparison of the refractory periods induced by hypertonic airway challenge and exercise in bronchial asthma. Am Rev Respir Dis 1987;135:822-5. 